The Quarterly Review of Economics and Finance, Vol. 35, No. 2, Summer, 1995, pages 119-152 Copyright (C) 1995 Trustees of the University of Illinois All rights of reproduction in any form reserved. ISSN 0033-5797

\title{
Aggregate Income Risks and Hedging Mechanisms
}

\author{
ROBERT J. SHILLER \\ Yale University and NBER
}

\begin{abstract}
Estimates are made, from time series data on real gross domestic products, of the standard deviation of returns in markets for perpetual claims on countries' incomes. The results indicate that there is much fundamental uncertainty to be hedged. Evidence is shown that there may be only minimal ability to cross hedge these returns in existing capital markets.

Methods of establishing markets for perpetual claims on aggregate incomes are examined. Such markets, by allowing hedging of these aggregate income risks, might make for dramatically more effective international macroeconomic risk sharing than is possible today. Retail institutions are described that might develop such markets and help the public with their risk management. However, the establishment of such markets would also incur the risk of major financial bubbles and panics.
\end{abstract}

This paper provides estimates of the amount of risk in aggregate incomes of countries around the world, and discusses mechanisms, futures markets, that might be set up to allow the hedging of such risk.

The risk that will be studied here is risk of fluctuations in Market present values of long streams of aggregate income flows. Hedging markets might best be set up in such a way that the markets establish such present values. The empirical work presented here allows us to assess the price variability in such hedging markets.

Markets for perpetual claims, in particular, perpetual futures (Shiller 1993) would allow trading of perpetual income streams and the price discovery would reveal present values. The perpetual futures markets would be cash settled based on measures of aggregate income, with a settlement formula that involves a regular capital gain and loss component, so that the futures price would work out to be the price of a claim on a perpetual income stream.

By allowing hedging of the capital value of a strcam of income, the hedging markets (let us call them macro markets) would allow hedging of the kind of longer-run macroeconomic risk that really matters to individuals. Nations or other groupings of people could use such markets to insure themselves against the prospect 
of a declining standard of living, against the prospect of relative poverty. By hedging such risks, the macro markets would allow the natural tendency for convergence of incomes to reduce inequality of incomes, by removing the shocks that disperse incomes. Thus, the establishment of such markets might make significant progress, in the long run, toward equalizing wealth across nations, regions, and, consequently, across individuals.

Only certain components of aggregate income fluctuations, such as corporate dividends, are easily hedgable and diversifiable today; the bulk of national incomes is not represented in any financial markets. Our stock markets are markets for claims on corporate dividends, yet corporate dividends are only a small part of national incomes. In the United States, dividends averaged only $2.91 \%$ (and corporate profits after taxes only $6.23 \%$ ) of national income from 1959 to 1992 . There is no direct way to hedge national incomes themselves, or components of aggregate incomes such as income accruing to labor, real estate, unincorporated businesses, and privately held corporations.

There could be national income futures markets for each country of the world; thus the empirical work presented here is worldwide in scope. Moreover, since national boundaries are not always the best criteria for defining income aggregates for hedging purposes, markets may also be established for other regions, and for aggregate income flows associated with human labor characteristics, and with major investments, such as investments in human capital or real estate. ${ }^{1}$

Section I of this paper discusses the theory of markets that discover capital values, with emphasis on perpetual futures markets. Section II presents estimates of the variability of returns in aggregate income perpetual futures contracts for most of the major countries of the world, computes a world market return, and presents some indications of the potential for cross hedging of macro risks in existing financial markets. Section III discusses the likely market structure if macro markets became fully established, identifies who are the likely shorts and longs in the markets and what retail institutions may help these markets to function. Section IV discusses measurement problems in constructing the indices of aggregate income that would be used in the cash settlement of macro futures markets. Section V concludes with an analysis of the potential risks and benefits of macro markets. Despite the theoretical attractiveness of important new hedging markets we should be cautious about establishing such markets. The creation of such markets might create problems. The aggregate stock market in the United States and elsewhere appears to show some excess volatility, and we cannot be sure that an aggregate income futures market will not also show such excess volatility. There could be endogenous booms and crashes in a macro futures market, that throw off resource allocation rather than direct it sensibly. 


\section{MARKETS THAT DISCOVER CAPITAL VALUES: PERPETUAL CLAIMS}

\section{Market Design}

The macro markets that are most likely to prove important are those that trade in clains on long steans of future incone, and thus are markets that price capital values of those streams. It would appear that there is more public interest in markets for capital values than there is in conventional futures markets that cash settle based on indices of income on the settlement date. Most futures markets today are constructed to price capital values. There are many stock index futures markets but nowhere in the world today is their any futures market that cash settles based on the next dividend accruing to a stock index portfolio; exchanges would have found it very natural to create such markets had there been any interest in them. While we cannot rule out that there might be some people who would want a conventional futures market cash settled on the next value of a dividend index, it would appcar that people are more concerned with hedging the value of their investments, which value collapses information about the indefinite future of the dividends accruing to these investments into today's price.

In order to create markets that price flows of income, we must create instruments that pay an amount to the bearer each period proportional to an income measure. These instruments would entail someone being required to pay the income index to those who hold the instrument.

The most direct and obvious way to create such markets would be to have issuers of an instrument promise to pay the income index value to investors in the instrument for a finite period of time. This would result in an instrument whose value represents the present value of the income flow up to the end of this period of time, and such instruments could prove useful. ${ }^{2}$ However, prices of such instruments would show a tendency to decline with time: the value is guaranteed to fall to zero after the last payment. It would be more natural to create a market in perpetual claims. By making the instrument perpetual, its price represents a claim on all future income payments, and thus represents the entire asset value of the cash flow.

Perpetual futures markets are futures markets in perpetual claims that are so constructed that they do not require the existence of any instrument promising to pay the income stream forever; they do not require any cash market. ${ }^{3}$ It is difficult to find an issuer who can guarantee paying the income index forever, but there is no need to find such an issuer. We can use the institution of futures markets to create perpetual instruments without requiring of anyone more than a day's participation in the markets.

Shorts would pay the income index to longs each day that they are in the con tract. Shorts would also have to pay a capital gain to (or reccive a capital loss from) longs, 
so that time periods are linked and so that the contract is effectively perpetual, and not a rollover of short instruments. Both shorts and longs would have to put up margin to guarantee their performance. Both sides would expect to be closed out of their position if they were unable to maintain their margin account. As long as there is a liquid market in the instruments hereby created, and if margin balances are sufficiently high, the risk of default is eliminated forever.

With perpetual futures, there would be, every day, a cash settlement, paid from shorts to longs; at time $t$ the settlement $s_{t}$ is given by:

$$
s_{t}=\left(f_{t}-f_{t-1}\right)+\left(d_{t}-r_{t-1} f_{t-1}\right)
$$

where $f_{t}$ and $f_{t-1}$ perpetual futures prices at days $t$ and $t-1$ respectively, so that $f_{t}-f_{t-1}$ is the capital gain from $t-1$ to $\mathrm{t}, d_{t}$ is the income index for day $t$, and $r_{t-1}$ the return on an alternative asset between day $t-1$ and day $t^{4}$ (Here, the letter $d$, for dividend, is used to represent the income index because it is to be thought of as a dividend on the perpetual claim.)

There are two possible interpretations of the cash settlement given by Equation 1 in the perpetual futures market. In the first interpretation, the market combines the daily resettlement of conventional futures with the final cash settlement that in conventional futures markets occurs only on the last day. Recall that in a conventional cash-settled futures market there is, every day $t$ until final settlement, a cash settlement $f_{t}-f_{t-1}$ in terms of the change in the futures price. Then, on the last day, day $T$, the final settlement is given not by the change in the futures price but by $p_{T}-f_{T-1}$ where $p_{T}$ is the cash market price index at time $T$. Thus, for conventional futures markets there are two different settlement formula, used at different times. In contrast, with perpetual futures we may regard both the daily resettlement and the final cash settlement as occurring every day. By this interpretation of the perpetual futures contract, the term $\left(f_{t}-f_{t-1}\right)$ corresponds to the usual daily resettlement, and the second term $\left(d_{t}-r_{t-1} f_{t-1}\right)$ corresponds to the final cash settlement. The term corresponding to final cash settlement looks a little different with perpetual futures: here the income (i.e., dividend) index replaces the cash price index in the settlement formula, and the permanent-income component $r_{t-1} f_{t-1}$ of $f_{t-1}$ replaces the $f_{t-1}$. By the second interpretation of the settlement formula, the settlement $s_{t}$ is just the excess return from $t-1$ to $t$ between an asset whose price at time $t-1$ is $f_{t-1}$ (and that pays dividend $d_{t}$ at time $t$ ) and an alternative asset that pays the return $r_{t-1}$ between $t-1$ and $t$.

How might the price $f_{t}$ be determined in the marketplace if there were such a perpetual futures market? Let us consider what the consumption Euler equation theory would say about this. In this theory, households are supposed to maximize expected utility $\mathrm{U}$ that is the expected present value of the instantaneous felicity $u($. of $c_{t}$, consumption at time $t$. 


$$
U=E_{t} \sum_{k=0}^{\infty} \lambda^{k} u\left(c_{t+k}\right)
$$

where $\lambda$ is the discount factor, the reciprocal of one plus the subjective rate of time preference.

Let us first, as a review, recall what such Euler equation models say about a conventional futures market that is one period from cash settlement, so that $s_{t+1}=p_{t+1}-f_{t}$. The basic Euler equation for a household that considers buying such a contract at time $t$, that must be satisfied if the household is optimizing, is:

$$
E_{t}\left(m_{t+1} s_{t+1}\right)=E_{l}\left(m_{t+1}\left(p_{t+1}-f_{t}\right)\right)=0
$$

where $m_{t+1}=u^{\prime}\left(c_{t+1}\right) / \pi_{t+1}$ is the marginal utility of a unit of currency at time $t+1\left(\pi_{t+1}\right.$ is the consumer price index at time $t+1)$. Obviously, if this equation is not satisfied, then the household must be able to improve expected utility by buying more of the contract (if the left-hand side is positive) or selling more of the contract (if the left-hand side is negative). Since households are presumed to be optimizing, then this equation must be satisfied. It follows that the futures price equals the expected cash price plus a risk premium that is determined by the covariance between the marginal utility $m_{t+1}$ of a unit of currency at time $t+1$ and the cash price $p_{t+1}$ :

$$
f_{t}=E_{t} p_{t+1}+\frac{\operatorname{cov}_{t}\left(m_{t+1}, p_{t+1}\right)}{E_{t} m_{t+1}}
$$

While conventional futures prices are determined thus in terms of expected future cash prices, at the same time we can say that, if the cash-market asset is storable, the futures price is determined by today's price and an interest rate. The possibility of zero-cost storage, and the assumption that positive quantities of the commodity are in storage, implies that:

$$
m_{t} p_{t}=\lambda E_{t}\left(m_{t+1} p_{t+1}\right)
$$

Moreover, if we have a risk free asset that pays $i_{t}$ between $t$ and $t+1$, we also have another Fuler equation:

$$
m_{t}=\left(1+i_{t}\right) \lambda E_{t} m_{t+1} .
$$

From Equation 3, it follows that $f_{t}=E_{t}\left(p_{t+1} m_{t+1}\right) / E_{t} m_{t+1}$ and so, using Equation 5, $f_{t}=m_{t} p_{t} /\left(\lambda E_{t} m_{t+1}\right)$ and hence from Equation $6:^{5}$

$$
f_{t}=p_{t}\left(1+i_{t}\right)
$$

Equation 7 is widely interpreted as asserting that futures prices have no relation to expected future prices, being determined only by price today. This can be true as well as futures prices being determined by expected future cash prices because there is a 


\section{QUARTERLY REVIEW OF ECONOMICS AND FINANCE}

relation, Equation 5, between the cash price today and the expected future cash price. The relation asserting that futures prices are related to expected future cash prices may be regarded as more fundamental, since it does not rely on the assumption of costless storage opportunities, or even the existence of a cash market at time $t$. (In our perpetual futures, there is not usually a cash market with any substantial liquidity.)

Let us now inquire how this analysis should be modified for perpetual futures. The basic Euler equation for perpetual futures is:

$$
E_{t}\left(m_{t+1}\left(f_{t+1}+d_{t+1}-\left(1+r_{t}\right) f_{t}\right)\right)=0
$$

Obviously, if this equation is not satisfied, the household can improve expected utility by buying or selling more of this futures contract; since households are presumed to be optimizing, the equation must be satisfied. This equation is the perpetual futures market analogue to Equation 3 relating futures price to expected future cash price. It follows that:

$$
f_{t}-\frac{E_{t}\left(m_{t+1}\left(f_{t+1}+d_{t+1}\right)\right)}{E_{t}\left(m_{t+1}\left(1+r_{t}\right)\right)} .
$$

Consider the special case where $m_{t+1}$ is uncorrelated with $f_{t+1}+d_{t+1}$ (as might happen if this cash market is small and unrelated to world market conditions) and $r_{t}$ is a constant $(=r)$. Then the $m_{t+1}$ drops out of Equation 9 and we find that the futures price $f_{t}$ is the present value, discounted by $r$, of $f_{t+1}+d_{t+1}$. Solving this relation forward, and ignoring the possibility of extraneous bubbles, we would find that the futures price is the present value of expected future dividends discounted by $r$. Thus, the futures exchange, by setting $r$, can create markets for present values for any desired discount rate. Setting a high value of $r$ in the contract would mean that the perpetual futures market is relatively short term. The futures exchanges could create an array of futures markets that are forward looking in various amounts by creating markets with an array of $r$ s. Such an array of contracts might be considered analogous to the array of maturities of futures contracts that are presently offered by futures exchanges, and yet each contract is perpetual, that is, does not grow shorter-term with time, so that there is no need for participants to roll over their positions as they expire. However, this present value result depends on the assumption that $f_{t+1}+d_{t+1}$ is uncorrelated with $m_{t+1}$; more generally, the discount factor in the present value formula would depend on a sort of risk premium that is related to this correlation.

Another special case to consider is that in which $r_{t}$ is the return on a competing asset that is freely traded. For any such asset, there is an Euler equation $m_{t}=\lambda E_{t}\left(m_{t+1}\left(1+r_{t}\right)\right)$. Substituting this equation for the denominator in Equation 9 , we find:

$$
f_{t}=E_{t}\left(\left(f_{t+1}+d_{t+1}\right) \lambda m_{t+1} / m_{t}\right)
$$

which is the usual Euler equation for the price $f_{l}$ of an asset that pays cash flow $d_{t+1}, d_{t+2}, \ldots$ It follows that, if there are no extraneous bubbles, the price of the 
perpetual futures contract would be the same as the price of the asset, were it traded. By this account, it does not matter what alternative asset return $r_{t}$ is chosen by the exchange for cash settlement, so long as the asset is freely tradable.

That the futures price will be the same as the market value (i.e., market present value) of the stream of dividends can be seen in a more robust way, without reference to the model that gave rise to the Euler equation, just by assuming the law of one price, that the value of any portfolio equals the value of its components. The value that the market places at time $t$ on the settlement $s_{t+1}$ must be zero, since anyone can have that settlement just by entering into a futures contract. It follows that the market value at time $t$ of $f_{t}\left(1+r_{t}\right)$ equals the market value at time $t$ of $d_{t+1}+f_{t+1}$. Since the market value of $f_{t}\left(1+r_{t}\right)$ must equal $f_{t}, f_{t}$ must equal the market value at time $t$ of $f_{t+1}+d_{t+1}$. By applying the same argument for $f_{t+1}$ here, proceeding by recursive substitution and assuming that the market value at time tof $f_{t+k}$ goes to zero as $k$ goes to infinity, we find that $f_{t}$ is the market value at time $t$ of the stream of future dividends.

Another way to see that $f_{t}$ should be the market present value of dividends is to note that by paying $f_{t}$ one can be assured receiving the infinite stream of dividends. One does this by buying one futures contract and investing the amount $f_{t}$ in the alternative asset. In each subsequent period $t+k, k>0$, one invests $f_{t+k}-f_{t}$ in the alternative asset. By the law of one price, then, and assuming that the present value of $f_{t+k}$ goes to zero as $k$ goes to infinity, the futures price $f_{t}$ must be the same as the price of a claim on the stream of dividends.

Yet another special case is that in which the alternative asset return $r_{t}$ is the return on the world portfolio of aggregate incone futures; this possibility will be considered below. It will be assumed in most of what follows that the variable $r_{t}$ in the settlement formula 1 is the return on a conventional liquid asset, such as a risk-free interest rate.

\section{Rational Speculative Bubbles}

A curious property of perpetual futures is that, unless some kind of cash-out option is imposed, there is the possibility of infinite rational speculative bubbles. Even negative bubbles, where prices fall perpetually down are possible, so long as the futures exchange allows negative futures prices. The law of one price may not hold, the futures market differing from the cash market just in that there is a rational bubble going on it.

The usual problems that prevent infinite rational speculative bubbles do not arise here, since futures prices are not prices of assets; they are used only in the settlement Equation 1 where they appear only in difference form. The equilibrium condition in futures market is that the total net worth is zero, not positive as in asset markets. The futures price can go off to infinity without necessarily making the stock of wealth go to infinity. Of course, an individual who continued to hold a long or short position in the futures market, reinvesting proceeds, would see his or her wealth go off to infinity, but the same is true in any financial market. 
Since prices appear only in difference form in the settlement Equation 1, one might say that the bubbles do not matter; in fact, however, they might introduce randomness in the price that is not related to the value of the item to be priced. Thus, to keep the perpetual futures price informative about the present value of the stream $d_{t}$, some kind of price limits may be needed. With perpetual futures, there is no arbitrage possibility that keeps the futures price in line with the cash market price, becausc there is no final settlement that ties down the futures price to the cash price at any date.

It would certainly seem natural for futures exchanges to prohibit negative prices. Futures prices could also be limited to some range around the dividend stream; even if the range is extremely wide, it should rule out infinite rational bubbles. Such price limits, of course, do not rule out irrational bubbles, temporary deviations of price due to herd-like or faddish behavior of investors, a concern that will be discussed in the conclusion below.

\section{MEASURING UNCERTAINTY ABOUT PRESENT VALUES OF INCOME}

\section{Econometric Methods}

How much short-run variability would there be in income present values, variability that would cause price volatility in perpetual income futures markets? If a futures market is to be successful, there must be enough noise in price to interest traders, enough uncertainty to concern hedgers.

National income and other income measures often behave rather smoothly through time. This smoothness might suggest that there is little uncertainty about the present value of aggregate incomes. If the income series is very smooth, then future values can be forecasted very well by pure extrapolation. If, then, there is in fact little uncertainty about future values, then there is little incentive to hedge, and, moreover, the price of the asset will not be very volatile.

The smoothness of an income series is no proof that a perpetual claim on incomes will be smooth. Dividends paid on corporate stocks also behave fairly smoothly through time (companies try to smooth nominal dividends) and this does not result in smooth prices of stocks.

Of course, if incomes are really smooth, so much so that an extrapolation of incomes is very successful in predicting future incomes out as far as is important in the context of the present value formula, then there will not be much uncertainty about the present value of future incomes, and so there cannot be much news about future incomes either. The same would be true if there were some other information variables, apart from incomes themselves, that are quite successful in forecasting incomes as far as is relevant for the present value formula. In these cases, and 
assuming that price is the present value of optimally forecasted future incomes, there will not be much variability of returns. In the extreme case where the future is known perfectly, then there will be no uncertainty at all about future incomes, and hence no variability in returns on claims on incomes. The question that one must address in viewing the income series is to what extent is the present value of this series forecastable.

To investigate the forccastability of present values, and to scc the conncction between this forecastability and the variability of prices in perpetual futures markets, I will use a log-linearized form of the present value model that John Campbell and I developed $(1988,1989) .{ }^{6}$ The log-linearized version is attractive because it deals in percentage changes rather than levels of variables, and hence is likely to deal with stationary series. In place of price, which may not be stationary, the model is cast in terms of a ratio, the dividend price ratio. We define $\delta_{t}$ as the (demeaned) natural log of the dividend price ratio, equal to $d_{t-1}-p_{t}$ (demeaned) where $d_{t-1}$ is lagged log dividend and $p_{t}$ is $\log$ price. The dividend is lagged one period since both $\delta_{t}$ and $p_{t}$ are supposed to be measured at the beginning of time $t$. The dividend $d_{t}$ paid over all of time $t$ is not available at the beginning of time $t$ to form the numerator of the ratio; indeed, conventionally defined dividend price ratios use lagged dividends for the numerator. The basic approximation can be represented as that $\delta_{t}$ is the expectation of the present value $\delta_{t}^{*}$ of the future changes in log dividends:

$$
\begin{gathered}
\delta_{t}=E \delta_{t}^{*} \\
\delta_{t}^{*} \equiv \sum_{j=0}^{\infty} \rho^{j} \Delta d_{t+j} \quad 0<\rho<1 .
\end{gathered}
$$

where $\Delta d_{t+i}$, the growth rate in dividend between period $t+i-1$ and $t+i$, is demeaned. This model can be interpreted as saying that (log) dividend price ratios are high when dividends are expected to decline over the future relevant to present values, and low when expected to rise. The parameter $\rho$ is the discount factor, determined by the point chosen for the linearization. Campbell and Shiller $(1988,1989)$ set this equal $\exp (-(s-g))$ where $s$ is the discount rate (computed as the average real return of the market over the historical sample) and $g$ is the growth rate of real dividends (computed as the average growth rate over the historical sample). The assumption here is that the discount factor $\rho$ is constant through time, though in fact variations in $\rho$ may well induce more volatility in asset prices. Associated with this approximation is a linear approximation $\xi_{t}$ for the (demeaned) one-period holding return between time $t$ and time $t+1$ :

$$
\xi_{t}=\delta_{t}-\rho \delta_{t+1}+\Delta d_{t}
$$

It follows from these definitions that: 


$$
\delta_{t}-\delta_{t}^{*}=\sum_{j=0}^{\infty} \rho j \xi_{t+k}
$$

This means that the difference between the log dividend-price ratio today and the ex-post-rational log dividend-price ratio is the present value of (demeaned) holding period yields. Moreover, since holding period returns are by this model serially uncorrelated, it follows that the variance of the sum on the right hand side of Equation 14 is the same as the sum of the variances. Therefore,

$$
\operatorname{var}\left(\xi_{t}\right)=\left(1-\rho^{2}\right) \operatorname{var}\left(\delta_{t}-\delta_{t}^{*}\right)
$$

Thus, the variance of returns is proportional to the variance of the unforecastable component of $\delta_{t}^{*}$. Since we do not have a market for claims on aggregate income, we do not observe the market forecast $\delta_{t}$ of $\delta_{t}^{*}$, and we cannot form the variance of the right-hand-side of the above expression. If we are to make an estimate of the variance of $\xi_{t}$, then we must specify an information set and a forecasting model for dividends.

To understand the issues here, it may be helpful to note that one could compute a time series of values of $\delta_{t}^{*}$ using a time series of actual dividend data, if one were willing to substitute zeros for values of $\Delta d_{t}$ for the periods beyond the near end of our time series; with long enough time series this procedure might work well enough in producing an approximation to $\delta_{i}^{*}$. If one then computed the variance of this constructed $\delta_{t}^{*}$ with a sample that ends substantially before the end of our time series data, then one would have a rough indication of the variability of the true $\delta_{t}^{*}$. But to get an estimate of the standard deviation of returns $\xi_{t}$, one must gain an impression how much of the variance of $\delta_{l}^{*}$ is forecastable. One could estimate the variance of $\xi_{t}$ by doing a time series regression with this constructed $\delta_{t}^{*}$ as dependent variable and a set of information variables available at time $t$ as independent variables. If one assumes that the market forms expectations linearly in terms of this information set, then the estimated variance of the error term in the regression can be used in Equation 15 for the variance of $\delta_{t}-\delta_{t}^{*}$, to provide an estimate of the variance of $\xi_{t}$.

Ultimately it will be difficult to estimate how much of the variability of $\delta_{t}^{*}$ is forecastable. The reason is that the series is dominated by long-term or low-frequency movements. There are not a lot of independent observations of $\delta_{t}^{*}$, not a lot of effective degrees of freedom. At the same time, there are many economic variables that have a strong low frequency component. There are too many candidate variables that might be used to forecast $\delta_{t}^{*}$ relative to the number of effective degrees of freedom. We do know, however, that since $\delta_{t}$ is the expectation conditional on publicly available information at time $t$ of $\delta_{t}$, the variance of $\delta_{t}^{*}$ is an upper bound on the variancc of $\delta_{t}-\delta_{t}^{*}$, and hence $\left(1-\rho^{2}\right)$ times this variance is an upper bound to the variance of $\xi_{\text {. }}$.

Of course, we can never be sure whether there might be other variables not included in our information set that would help us to forecast $\delta_{t}^{*}$, and thereby reduce 
the variance of $\delta_{t}-\delta_{t}^{*}$. If we consider that the public may have superior information, then our estimated variance may be regarded as a sort of upper bound (this is the West inequality 1988b).

Despite the essential ambiguity of any measure of the forecastability of $\delta_{t}^{*}$, it is worthwhile pursuing at least whether the smoothness observed in short-run movements in $\Delta d_{t}$ is suggestive that $\delta_{t}^{*}$ is substantially forecastable. For this, and to avoid having to use the approximation implicit in use of a constructed $\delta_{t}^{*}$, we may usc the time series model developed by Campbell and Shiller $(1988,1989)$. Consider the first order vector autoregressive model $\mathbf{z}_{t}=A \mathbf{z}_{t-1}+u_{t}$ where the $k$-element vector $\mathbf{z}_{t}$ has first element $\Delta d_{t-1}$, and has other elements that are other information variables available at time $t$, and where the $k$-element vector $\mathbf{u}_{t}$ is a vector error term. Since it is presumed here that the price $p_{t}$ is the price at the beginning of year $t$, lagged dividends, but not year $t$ dividends, are in the information set on which the price $p_{t}$ can be based. This accords with our defining $\delta_{t}$ in terms of the lagged dividend; recall that this is the usual definition of the dividend-price ratio. Here, the other information variables included in $\mathbf{z}_{t}$ will be $\Delta d_{t-2}, \Delta d_{t-3}$, etc., in which case the first order autoregressive model for $\mathbf{z}_{t}$ is really a higher order scalar autoregressive model for $\Delta d_{t}$ in companion form, and the elements of $\mathbf{u}_{t}$ after the first are all zero. Following Campbell and Shiller, since $E_{t} z_{t+k}=A^{k} \mathbf{z}_{t}$, it follows that:

$$
\delta_{t}=-e 1^{\prime} A(I-\rho A)^{-1} \mathbf{z}_{t}
$$

where $e l$ is a k-element vector whose first element is 1 , and the others zero. It also follows that $\xi_{t}$ is proportional to the innovation $\mathbf{u}_{t+1}$ in $\mathbf{z}_{t+1}:{ }^{7}$

$$
\xi_{t}=e 1^{\prime}(I-\rho A)^{-1} \mathbf{u}_{t+1}
$$

and hence:

$$
\operatorname{var}\left(\xi_{t}\right)=e 1^{\prime}(I-\rho A)^{-1} \Omega(I-\rho A)^{-1^{\prime}} e 1 .
$$

We can therefore estimate the time series model for $\mathbf{z}_{t}$ and thereby estimate the variance of $\xi_{t}$ under the assumption that the market uses this model to forecast. In the sense defined by West $(1988 \mathrm{~b})$, this is also an upper bound to the variance of $\xi_{t}$ since the market may have more information to forecast.

As a check on this method of estimating variances of returns from dividend data, I first estimated the implied variance of Standard and Poor stork returns using data from 1871 to 1992 on real Standard and Poor dividends, updated from data in Shiller (1989), to see how close the estimated variance of returns corresponds to actual variance. ${ }^{8}$ Past experience with methods analogous to those described here applied to such stock market data show that the estimated variance of $\xi_{t}$ tend to be lower than the variance of actual returns; this is the excess volatility result noted many times (see Shiller 1989; West 1988a for a survey.) Still, such methods do suggest substantial volatility for the stock market. ${ }^{9}$ Here, the matrix A was estimated by regressing the vector $\mathbf{z}_{t}$ on $\mathbf{z}_{t-1}$ with ordinary least squares, where $\mathbf{z}_{t}$ has $k$ elements, $\Delta d_{t-j} j=1, \ldots k$. 
The value of $\rho$ (the discount factor) assumed was 0.936 , the same value that was used for the U. S. stock market in Campbell and Shiller (1988, 1989). When the autoregressive model for real dividends was estimated with one lag, $k=1$, the stock return volatility implied from Equation 18 was $14.67 \%$, but as $k$ was increased the implied volatility steadily declined. With $k=3$ the standard deviation of $\xi_{t}$ was $12.13 \%$, with $k$ $=5$ it was $10.90 \%$, with $k=10$ it was $10.47 \%$, with $k=15$ it was $8.14 \%$, with $k=20$ it was $7.00 \%$, with $k=30$ it was $5.29 \% .{ }^{10}$ Over the same sample period for which these returns were calculated in the $k=10$ case (1882 to 1991 ), actual returns computed from these data had a standard deviation of $18.13 \%$, nearly twice the standard deviation of our theoretical returns; over this sample period the correlation between actual and theoretical returns was 0.36 . This is not a smashing success for the expected present value model in predicting returns, especially considering that the correlation between the growth rate of dividends and stock market returns was 0.94 over this same sample, indicating that the market overreacts to dividends relative to the present value model, as has been noted before (see Shiller 1989). The tendency of the standard deviation of theoretical returns to decline with $k$ apparently reflects the finding of Campbell and Shiller $(1988,1989)$ that dividends relative to long moving averages of dividends help forecast dividends the best: when log real dividends are low relative to a long moving average of log real dividends, log real dividends tend to increase, when they are low, they tend to decrease. The regression coefficients in the high $k$ instances tend to be pretty consistently negative and, very roughly speaking, to die out exponentially with lag. An exponentially weighted distributed lag on past growth rates is, of course, proportional to the latest log dividend minus an exponentially weighted distributed lag on log dividends; for example, proportional to the current log dividend minus a long average of lagged $\log$ dividends.

\section{Results with Individual Countries}

While this preliminary check on the method using stock market data suggests that the method is not terribly accurate in predicting the standard deviation of returns, perhaps the method is good enough to give us a rough indication of the order of magnitude of the volatility we might observe in a perpetual futures market in national incomes. Thus, the same method of estimating the standard deviation of returns was applied to each of the countries of the world for which the Penn World Table Mark 5.5 (Summers and Heston, 1988, 1991) had real gross domestic product data for the years 1950 to $1990 .{ }^{11}$ In applying this method, the value of rho chosen by Campbell and Shiller $(1988,1989)$ was the same as for the stock market, $0.936{ }^{12}$ Alternative estimations with the number of lags in the autoregression $k$ equals 5,10 , and 15 years were undertaken; since the results were broadly similar only the results with $k=10$ are displayed here. 
Table 1 Column 1 shows the estimated standard deviations of these theoretical returns for 54 countries in hypothetical real gross domestic product markets, computed from Equation 18. We see from the table that the standard deviations of returns in the national income perpetual futures market are often as high as, or higher than, the standard deviations of returns that this method predicts for stock markets.

The estimated variances of returns might of course be lowered if other forecasting variables were used, as for example, the forecasting variables used by Barro (1991). Putting in a simple time trend in the forecasting regression for dividends might also lower variances dramatically. But as argued above, we can never be sure how much the forecastability of national incomes can really be improved, since there is ultimately a degrees of freedom problem; there are too many potential forecasting variables.

The standard deviation of return in this market is extremely low for the United States, and nearly as low for the other English speaking countries. It is also low for many, though not all, European countries. This means that, over this sample period, the present valuc of national income has been quite forecastable. That the United States has such a low standard deviation of returns seems unfortunate, given that the United States is the likely testing ground for most innovative futures contracts. On the other hand, even with a standard deviation of only $1.62 \%$, the total dollar value of the hedgable risk in the United States far exceeds that of the stock markets in the United States, since the present value of national income is over an order of magnitude larger than the present value of corporate earnings. We may also note that the fact that the period 1950-1990 was a highly forecastable one does not mean that in other time periods gross domestic product is as forecastable. Indeed, when the sample period is extended for the United States, where the autoregressive model is estimated using per capita real GNP data from 1889 to 1992, then the standard deviation of returns (estimated with the identical procedure with ten lags in the autoregression but using the longer sample period) from 1900 to 1992 is $4.72 \% .^{13}$ We might also take from the experience of other countries that the United States is potentially vulnerable to large shocks as well. Indeed, the recent public concern with declining competitiveness of the United States in the world markets suggests that a perpetual futures market in the U.S. national income might indeed show substantial volatility.

Evidence that risk sharing internationally is not optimal can be found by comparing consumption growth patterns across countries, on the premise that if there were complete sharing of risk internationally, there would be perfect correlation across countries in consumption growth rates. Backus, Kehoe and Kydland (1992) found that correlations since 1960 of contemporaneous consumption (filtered to elininate low frequency movements, below business cycle frequency) between the U. S. and 11 other major nations were quite low. Only Canada had a correlation greater than a half; three were negative. ${ }^{14}$ However, the low correlation might be attributable to country-specific taste shocks affecting saving behavior rather than 
Table 1. Estimated Return Standardized Deviations and Other Statistics Perpetual Futures Markets in Per Capita Real Gross Domestic Products

\begin{tabular}{|c|c|c|c|c|}
\hline Country & $\begin{array}{c}\text { (1) } \\
\text { Standard } \\
\text { Deviation of } \\
\text { Return in Market } \\
\text { for Perpetual } \\
\text { Claim on GDP }\end{array}$ & $\begin{array}{c}(2) \\
\text { Value of Country } \\
\text { (1990 Present } \\
\text { Value of Real } \\
\text { GDP, 1990 \$US } \\
\text { Billions) }\end{array}$ & $\begin{array}{c}\text { (3) } \\
\mathbf{R}^{2} \\
\text { (Country } \\
\text { Return on } \\
\text { World Market } \\
\text { Return) }\end{array}$ & $\begin{array}{c}\text { (4) } \\
\text { Beta } \\
\text { (for Return in } \\
\text { Perpetual Futures } \\
\text { Market for GDP) }\end{array}$ \\
\hline Argentina & $9.86 \%$ & 2460 & 0.05 & 1.14 \\
\hline Australia & $3.18 \%$ & 4479 & 0.30 & 0.92 \\
\hline Austria & $3.18 \%$ & 1608 & 0.44 & 1.09 \\
\hline Belgium & $3.71 \%$ & 2201 & 0.47 & 1.34 \\
\hline Bolivia & $5.45 \%$ & 178 & 0.14 & 1.08 \\
\hline Brazil & $5.86 \%$ & 9776 & 0.12 & 1.09 \\
\hline Canada & $2.56 \%$ & 8155 & 0.31 & 0.73 \\
\hline Chile & $4.90 \%$ & 978 & 0.29 & 1.38 \\
\hline Colombia & $3.42 \%$ & 1783 & 0.30 & 0.99 \\
\hline Costa Rica & $6.35 \%$ & 170 & 0.19 & 1.46 \\
\hline Cyprus & $3.22 \%$ & 98 & 0.31 & 0.94 \\
\hline Denmark & $3.56 \%$ & 1201 & 0.14 & 0.71 \\
\hline Dominica & $6.75 \%$ & 285 & 0.00 & 0.20 \\
\hline Ecutador & $5.89 \%$ & 450 & 0.00 & 0.07 \\
\hline Egypt & $3.33 \%$ & 1669 & 0.01 & -0.13 \\
\hline Finland & $3.43 \%$ & 1288 & 0.06 & 0.44 \\
\hline France & $5.27 \%$ & 13570 & 0.44 & 1.83 \\
\hline Germany (West) & $4.39 \%$ & 15638 & 0.43 & 1.44 \\
\hline Greece & $7.87 \%$ & 1107 & 0.12 & 1.46 \\
\hline Guatemala & $6.13 \%$ & 316 & 0.27 & 1.67 \\
\hline Guyana & $11.04 \%$ & 14 & 0.03 & 0.98 \\
\hline Honduras & $4.58 \%$ & 120 & 0.23 & 1.16 \\
\hline India & $5.10 \%$ & 14619 & 0.01 & -0.20 \\
\hline Ireland & $2.79 \%$ & 507 & 0.15 & 0.57 \\
\hline Iceland & $4.53 \%$ & 59 & 0.02 & -0.31 \\
\hline Italy & $5.08 \%$ & 13543 & 0.43 & 1.71 \\
\hline Japan & $8.38 \%$ & 29934 & 0.36 & 2.67 \\
\hline Kenya & $4.40 \%$ & 355 & 0.00 & -0.02 \\
\hline Luxembourg & $2.40 \%$ & 111 & 0.10 & 0.41 \\
\hline Mauritius & $6.20 \%$ & 110 & 0.01 & -0.28 \\
\hline Mexico & $6.01 \%$ & 7608 & 0.12 & 1.08 \\
\hline Morocco & $3.01 \%$ & 855 & 0.04 & 0.30 \\
\hline Netherlands & $4.72 \%$ & 3193 & 0.34 & 1.45 \\
\hline New Zealand & $2.85 \%$ & 684 & 0.32 & 0.85 \\
\hline Nigeria & $10.74 \%$ & 1179 & 0.08 & 1.54 \\
\hline Norway & $2.21 \%$ & 1049 & 0.01 & 0.09 \\
\hline Pakistan & $3.07 \%$ & 2612 & 0.01 & 0.12 \\
\hline Panama & $7.08 \%$ & 97 & 0.00 & 0.25 \\
\hline Paraguay & $6.11 \%$ & 157 & 0.00 & 0.17 \\
\hline Penl & $11.06 \%$ & 984 & 0.00 & -0.29 \\
\hline Philippines & $3.68 \%$ & 1602 & 0.01 & 0.15 \\
\hline
\end{tabular}


Table 1. (continued)

\begin{tabular}{lcccc}
\hline & $\begin{array}{c}\text { (1) } \\
\text { Standard } \\
\text { Deviation of } \\
\text { Return in Market } \\
\text { for Perpetual } \\
\text { Claim on GDP }\end{array}$ & $\begin{array}{c}\text { Value of Country } \\
(\mathbf{1 9 9 0} \text { Present } \\
\text { Value of Real } \\
\text { GDP, 1990 \$US } \\
\text { Billions) }\end{array}$ & $\begin{array}{c}\text { (3) } \\
\mathbf{R}^{2} \\
\text { (Country } \\
\text { Return on } \\
\text { World Market } \\
\text { Return) }\end{array}$ & $\begin{array}{c}\text { (4) } \\
\text { Perpetual Futures } \\
\text { Market for GDP) }\end{array}$ \\
\hline Portugal & $7.00 \%$ & 1115 & 0.24 & 1.81 \\
El Salvador & $9.20 \%$ & 209 & 0.03 & 0.89 \\
South Africa & $8.68 \%$ & 2272 & 0.08 & 1.29 \\
Spain & $\mathbf{6 . 6 0 \%}$ & 5631 & 0.09 & 1.04 \\
Sweden & $3.75 \%$ & 2194 & 0.00 & 0.12 \\
Switzerland & $4.33 \%$ & 1986 & 0.33 & 1.33 \\
Thailand & $5.02 \%$ & 3125 & 0.22 & 1.21 \\
Trinidad \& Tobago & $8.75 \%$ & 157 & 0.01 & 0.49 \\
Turkey & $3.59 \%$ & 3151 & 0.01 & -0.16 \\
United Kingdom & $1.14 \%$ & 13616 & 0.05 & 0.13 \\
United States & $1.62 \%$ & 81044 & 0.49 & 0.59 \\
Uruguay & $4.44 \%$ & 236 & 0.11 & 0.76 \\
Venezuela & $9.18 \%$ & 2385 & 0.01 & 0.35 \\
\hline
\end{tabular}

Source: Author's calculations as described in text using per capita real gooss domestic product and population data, both from the Penn World Table Mark 5.5 For data description, see Summers and Heston (1988, 1991).

inability to hedge (Stockman and Tesar 1990). That such taste shocks are plausible compromises the ability of consumption correlations to reveal the extent of unhedged risk.

\section{World Market Return and Betas}

There is a more direct way than these consumption comparisons to see whether thcre is much unhcdged risk: comparing the variance of the world portfolio with the variance of individual country market futures market returns. If returns on the world portfolio are smaller than returns on country portfolios, then, assuming that there are now no markets to handle such risk, we show an advantage for countries using futures market to swap, in effect, their individual returns for the world returns.

To make this comparison, the first step was to compute the expected present value of the gross domestic product for each country to serve as weights in the computation of return on the world portfolio. The expected present value was produced for each country by dividing the real gross domestic product for that country and that year by the real dividend price ratio for that year computcd from Equation 16 in terms of lagged real income growth. The 1990 value of this expected present value is shown in column 2 of Table $1 .{ }^{15}$ Note that the values of each country are much higher than the usually defined national wealth for that country. For 


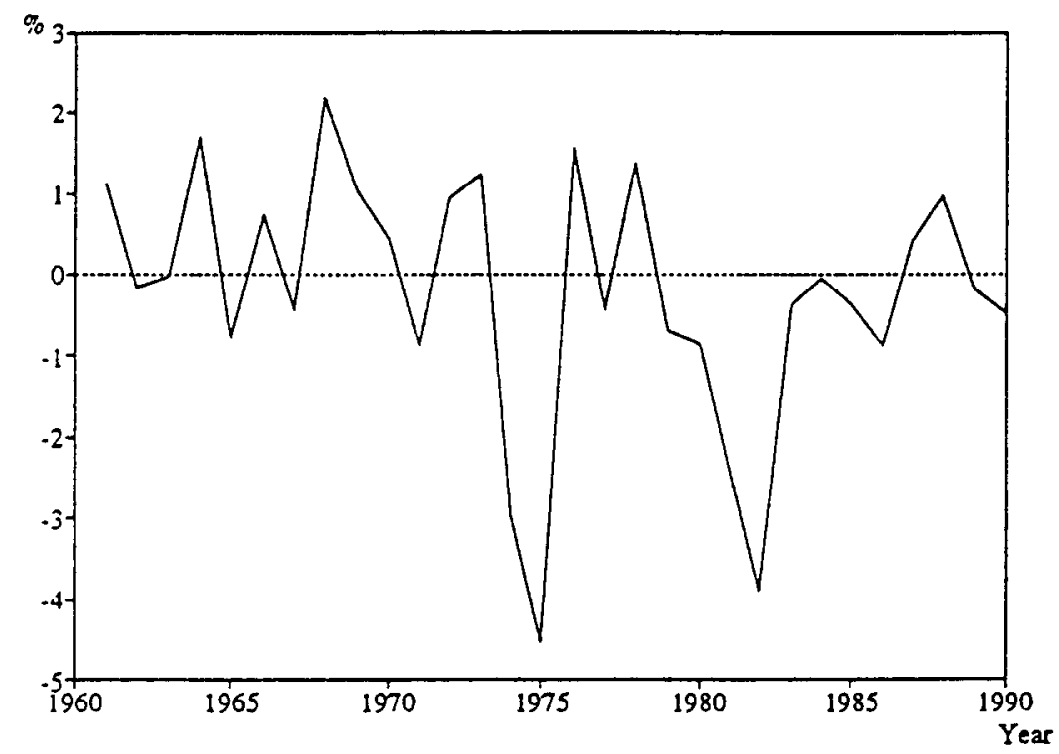

Figure 1. Estimated World Income Market Returns, Demeaned, 1961-1990, in Annual Percent.

Source: Calculations described in text from Penn World Table 5.5 data on real gross domestic products 1950-1990

example, the value of the United States is shown there to be $\$ 81$ trillion in 1990 , much higher than the $\$ 18$ trillion domestic wealth in the Flow of Funds Account (Board of Governors of the Federal Reserve System 1992). ${ }^{16}$ This discrepancy is of course what we would expect given that historically roughly three quarters of national income is labor income, whose capitalized value is not included in conventional measures of wealth.

Having estimated real returns time series and value weights for each of the $\mathbf{5 4}$ countries, we compute a world real return series by forming a weighted average of these returns, the weight given to each country in a given year proportional to the value of the outstanding perpetual futures market for the gross domestic product of that country. Of course, this estimated world return is not likely to be a very accurate indicator of actual returns in markets for world income, because of our lack of knowledge of actual information sets and because of our inability to model speculative price changes. Still it is possible to compute a rough indication of world returns that will give us a crude sense how variable such returns might be, and allow us to get some sense how much returns in different countries might correlate with each other.

Figure 1 shows a plot for the years 1961-1990 of this world real return series. The standard deviation of the real return (after a degrecs of frecdom correction that was employed because this real return is based on the residual of a regression) is only $1.90 \%$, suggesting that a lot of the risk of national incomes can be diversified away internationally. This suggests that the world market risk premium will be very small, 
and that there might be little backwardation in macro futures markets. Still, we should not understate the world market volatility; there have been some fairly important market turns, notably after the 1973 oil crisis, when there was a two-year return of $-7.36 \%$.

Although world market return is probably not well measured by this method, it is still instructive to compute country betas, to get some idea how much countries might differ in their exposure to world risk. Betas were computed here for the perpetual futures returns of each of the 54 countries, by regressing the country return on the market return. The $R^{2}$ of each regression is shown in Table 1, column 3; note that the $\mathbf{R}^{2}$ is usually quite low, reflecting the large idiosyncratic risks that countries are now bearing. The estimated betas appear in Table 1, column 4 . Note that there is a lot of variability of the betas across countries. The beta for the United States is only 0.59 . One might have expected higher, since the United States has a major weight in the world real return series (it accounted for $30.7 \%$ of market value as computed here in 1990). But, the standard deviation of the United States return is estimated here to be quite low, and so it has only a small direct effect on the world return.

\section{Cross Hedging}

Could market participants take a position in some other financial market, other than macro markets, to lay off their aggregate income risks? It is conceivable that the price in a perpetual futures market would be very closely correlated with the price of, say, corporate stocks. Then, there would be no need to establish the macro markets.

It is not an easy matter to resolve to what extent the cross hedging might work, since we do not now observe the market price of a claim on a stream of aggregate income. The best we can do is to make inferences based on a comparison of the stream of aggregate incomes with the stream of dividends on existing financial assets. We must be careful to compare flows with flows, and not compare flows with stocks.

A complicating factor, in trying to judge the extent to which prices in macro markets might correlate with prices in cxisting financial markets is that there might be some correlation in prices even if there is no correlation at all between the aggregate income in the macro market and aggregate dividend series in the existing financial markets. One way that this can come about is that there might be information pooling (Beltratti and Shiller 1993). An information variable may exist that reveals, say, the sum of the aggregate income series for the macro market and the dividend series for the financial market. Negative information pooling may also eliminate any correlation in price changes between the two markets even if the aggregate income and dividend series are positively correlated.

Examination of existing long time series of U. S. real per capita gross national product with real dividends accruing to the Standard and Poor Composite Stock Price 


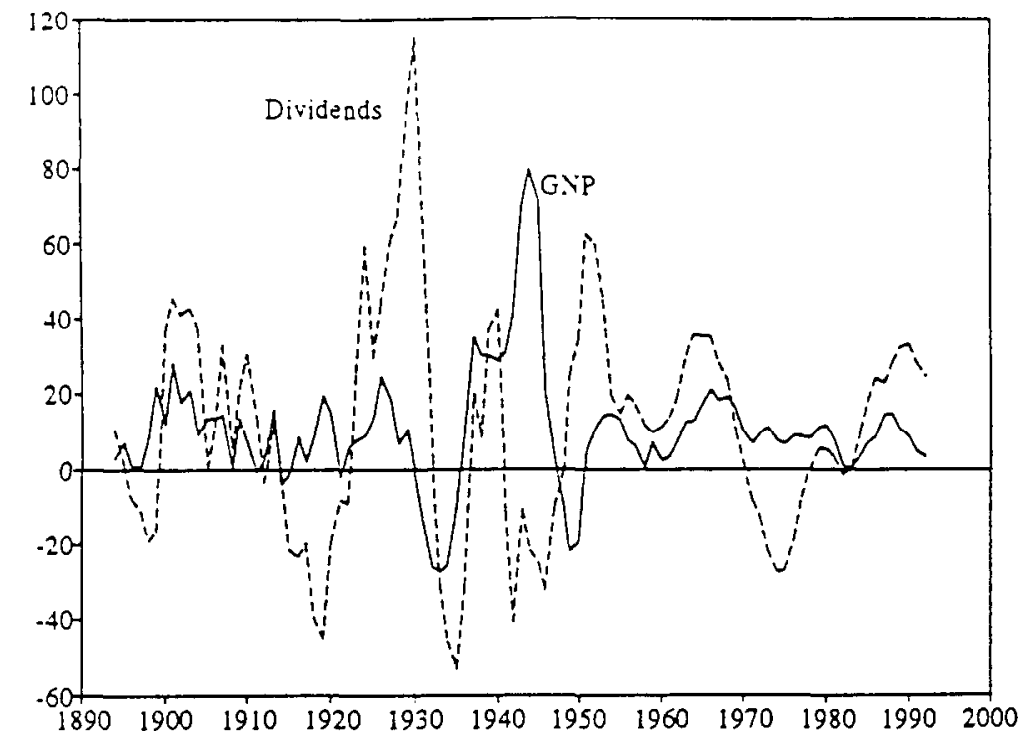

Figure 2. Growth rates for five year periods ending in year shown for real Standard and Poor dividends (dashed line) and real per capita U.S. GNP (solid line), 1894 1992.

Source: Shiuller (1989) and U.S. Department of Commerce.

Index reveals that the two series have virtually no relation. Five-year growth rates for both series are plotted in Figure 2 for each year 1894-1992. The correlation 1894 to 1992 of five-year growth rates in real dividends accruing to the Standard and Poor Composite Index with five-year growth rates in real per capita GNP is only a minuscule $2.81 \%$; with five year growth rates in real earnings the correlation is only $20.66 \% .{ }^{17}$

We can also compare estimated returns in the market for U. S. GNP with estimated returns in the market for corporate dividends, using the method already described to compute returns. Thus, proceeding as before, a ten-lag autoregressive model for changes in $\log$ real per capita U. S. GNP was estimated where the dependent variable ranged from 1900 to 1992 . With this method, the correlation coefficient for the years 1900 to 1992 between estimated returns (produced above from dividend series using Equation 17) in the U. S. stock market and the returns computed using Equation 17 for the U. S. GNP market is $24.99 \%$. Over the more recent sample 1964-1992 the correlation coefficient is $18.14 \%$. Thus, there appears to be very little correlation between the market for GNP and the stock market, and little scope for cross hedging.

Atkeson and Bayoumi (1991) attempted to find some evidence whether labor income fluctuations are in fact hedged in existing capital markets. They used time series regressions for each of various regions. In each regression, changes in per capita income from capital in that region was the dependent variable. The independent variables were changes in per capita income from capital for a broader 
aggregate of regions, changes in per capita income from labor in that region, and changes in capital product per capita for that region. The last independent variable is measured from the production side of accounts, rather than income side. The coefficient of the change in per capita income from labor term is of interest here: if people in that region were using the capital markets perfectly to hedge, then we might expect a coefficient of the change in per capita income from labor in that region of minus one. They ran these regressions with the constraint that the coefficients were the same across regions. When the regions were the states of the United States of America 1966-1986, the estimated coefficient of the change in per capita income from labor was -0.004 . Although this coefficient was significant at conventional levels, it was far from minus one; it was really inconsequential in magnitude. The coefficient of change in aggregate per capita income from capital was 0.983 , virtually 1.000 , the coefficient of the change in capital product per capita 0.022, virtually zero. When the regions were six members of the European Common Market (Germany, France, the United Kingdom, Belgium, Netherlands and Greece) 1970-1987, and the aggregate across regions was the sum of the incomes for the six countries, the coefficient of the change in per capita income from labor was -0.045 . This is a little more substantially negative than was the case for the individual states in the United States, but still very far from minus one.

There are many reasons to expect that it will be difficult to hedge regional or national labor income risk in existing capital markets. The value of a claim on corporate dividends should be very different from that of a claim on, say, the labor income that comprises the bulk of regional or national incomes. These two markets would really be pricing different factors of production. The output of corporations is typically sold on world markets, and reflects international conditions. Corporations are increasingly international, and move their operations around the world. Labor is relatively immobile, much of it engaged in activities that are not directly connected with corporate activities.

For most of the countries included in the econometric study above, stock markets are less important to their respective economies than is the case in the United States, and in many cases stock markets are nonexistent. For these countries, there is much less likelihood that cross hedging on any existing markets could be effective in reducing income risk.

\section{MARKET STRUCTURE AND ASSOCIATED INSTITUTIONS}

\section{Hedging Income Risk in Today's Markets}

There has been remarkably little attention paid to developing new methods for efficiently sharing risk about aggregate income. ${ }^{18}$ All of the discussion in theoretical finance about optimal diversification should have, it would seem, led researchers to 
an important mission: helping people diversify their major income risks. What we have instead are little patches here and there, without any recognition of the ultimate objective of allowing full diversification of risks that are most important to individuals.

Taxes and transfers in place today represent partial insurance against income fluctuations. With an income tax, tax payments fall when individual income falls. With the unemployment insurance, welfare, and other federal programs, transfers will increase for an individual when individual income declines. These government programs, since they are enforced on everyone, solve the problem of selection bias that might plague private companies that tried to start income insurance plans (people who signed up for the plans would be those who have reason to expect that their own income was insecure) although the government programs do not solve the moral hazard problem, the disincentive to work hard or at all that is created by the insurance.

The federal tax system in the United States involves only a small amount of interregional sharing of risk. Sala-i-Martin and Sachs (1992) estimate, using data on the states of the United States, that a one dollar reduction in a state's per-capita income causes a decline in federal taxes of about 34 cents and an increase in federal transfers of about 6 cents. These figures were computed using a cross-sectional regression, and hence hold aggregate income constant. The federal government is of course unable to insure against aggregate income fluctuations without entering into risk-sharing agreements with foreign countries. What evidence there is suggests that intercountry risk sharing is negligible even within an organızed common market. Sala-i-Martin and Sachs also did some rough calculations that indicated that a one dollar shock to aggregate regional GNP within the EEC will reduce tax payments to the EEC by only half a cent. Apparently it is difficult, politically, for countries to agree on risk sharing.

The kind of risk sharing that is imposed by income taxes and transfers is not optimal. The tax component represents incomplete risk sharing, and the transfer component of the risk sharing is limited to extreme cases.

Other forms of risk sharing have been discussed by economists. For example, there has been attention to educational loan programs whose repayment is contingent on the borrower's lifetime income. The Educational Opportunity Bank (U.S. Panel on Educational Innovation, 1967) was one such risk-sharing arrangement. Although this bank was never set up, Yale University in 1970 created a Tuition Postponement Option that involved such lifetime income risk sharing, see Tobin (1973). The loan markets created by these programs do help with a clear problem in financing higher education (the inability of borrowing against uncertain future income) but do relatively little for the big problem of sharing income risk. 


\section{Shorts and Longs in a World Market for Risk}

In contrast to the above-mentioned risk sharing mechanisms, the macro markets proposed here would confront the problem of macroeconomic risk management head on, allowing much diversification. The markets will let people hedge their specific risks and invest around the world. ${ }^{19}$

Income risk would be reduced in macro futures markets by making arrangements whereby current world income is shared. The losers in these markets (those who shorted the market for their own incomes and saw their incomes increase) give wealth to the winners in these markets (who hedged and saw their own incomes decline) to compensate the latter for their lower expected future income. Those who decide to short their own macro markets who also go long in world macro markets are effectively deciding just to share income, the short-run movements in the market price this period revealing the benefits or losses to agreeing to participate in such sharing this period.

Let us consider explicitly some possible hedging arrangements. Let us begin by imagining that the household deals directly in the futures market itself, even though most such dealings would likely be intermediated by retail institutions. Suppose, for illustration, that a household's income correlates perfectly with a macroeconomic aggregate represented by a futures market. Suppose that, at time 0 , the household sells short enough contracts in the futures market so that the income payment that it must make to the longs is exactly equal to its income. (We will defer for the moment consideration of the household's also taking a long position in world macro futures markets.) The number of contracts to sell short equals the household's income at time 0 divided by the value at time 0 of the income index used to settle the contract. Then, the household's total cash flow, the income plus settlement, no longer is affected directly by the income. Supposing for simplicity that the household sold one contract, the household then receives in period 1 the amount $r_{0} f_{0}+f_{0}-f_{1}$. This creates for the household the option of consuming the amount $r_{0} f_{0}$ and investing the proceeds $f_{0}-f_{1}$ in the asset that yields the return $r$. (If $f_{0}-f_{1}$ is negative, the household must sell of some of its investments in this asset or short the alternative asset). Next period, time 2, the household who stays in the same futures contract receives $r_{1} f_{0}+f_{1}-f_{2}$. It can then consume $r_{1} f_{0}$ and reinvest the proceeds in the alternative asset. If the household continues to do this indefinitely, it can consume the amount $r_{t} f_{0}$ at each future time period $t$. The household will have exchanged its income for an income equal to the rate $r$ times the value at time 0 of its claim on future income. (It should be remembered that if the household income is not perfectly correlated with the index, the household still bears the risk of the component of its income that is not correlated with the index that is used to cash settle the futures market.)

There is of course the consideration that a hedging household that makes losses in the income future market may wind up unable to meet margin calls. This would 
happen if the household's own income rose far enough to wipe out its liquid assets. If the household were to deplete its store of liquid assets, then it might find that its income would no longer be hedgable. This possibility does not completely vitiate the hedging function of the macro market, it would only mean that not everyone can use the macro market at all times to hedge.

The problem that risk of labor income might exceed the property income could be reduced if it were possible for individuals to sign contracts to pay from their own future income in exchange for cash today to meet margin requirements. In practice, of course, the ability of individuals with zero net worth to borrow against future income is quite limited, partly because of the difficulty of enforcing the contract and partly because of personal bankruptcy laws. Setting up institutions to allow people to sell claims on their own future incomes is of course analogous to creating a market for such claims, but it is not the same as creating a liquid market for a perpetual stream of future income. The household would need to do no more than find someone who knew it well (e.g., a local banker) who would be willing to buy a claim on its future income. Such claims would be inherently heterogeneous, differing in payout structures and risks of default, and so an index of prices in that market may not work well to cash settle futures contracts.

Our laws and institutions might be changed to make it easier for people to sell claims on their future incomes. Governments are ultimately able to enforce payments by individuals (witness our income tax laws) and they should be able to do that with payments occasioned by losses in macro futures markets. Of course, enforcing really large payments out of income as the result of losses in futures markets might incur widespread resentment, and might be politically difficult to enforce.

If a household finds it difficult, because of inability to commit to pay in the future, to hedge all of its income risk, it can, so long as it is able to commit to pay from some of its future income flows, still hedge some of it. The household could follow the strategy of hedging a fraction of its income in the macro futures market, and raising the fraction if its income should go down, lowering it if it goes up. If income should go down, the household has winnings in the futures market that would increase its ability to meet margin calls, and so the household is able to hedge a higher fraction of its income. If income should go up, the household loses some of its ability to hedge, but at the same time the household is better off and so does not need to hedge so much. Such a strategy may be called a dynamic portfolio strategy for replicating an out-of-the-money put on income. The household is, if it responds in the proper manner in its hedging to its income fluctuations, effectively buying a put on margin that creates a floor on the present value of its income below the present value of its current income. The effective price of such a put would be fairly small if the floor is sufficiently low. Thus, even though the household may be unable due to inability to commit to pay in the future to stabilize its income completely, it can buy insurance against disastrous decreases in its income. ${ }^{20}$ 
The analysis so far neglects to consider whether the household wants to exchange the income after hedging, $r_{t} f_{0}$, for some other flow of income, other than the rate $r_{t}$ used in the settlement formula. The reason it might is that the household could expect a higher return for given risk if it accepted some risk. There is reason to expect that an incentive will be created for people to do this, since we have described so far only a short-side demand for the macro contracts; futures prices have to be set so that someone is long.

Investors have an incentive to seek out the best return for their investments relative to risk. The futures markets will thus find a futures price with sufficient backwardation that investors will want to bear the risk. The term backwardation must be defined for perpetual futures contracts: backwardation here will mean a tendency for the settlement $s_{t}$ in Equation 1 to have a positive mean if the alternative asset is the risk free rate, or to have a mean which is greater than minus the risk premium of the alternative asset if the alternative asset is risky. Backwardation is a tendency for longs to earn a risk premium over the risk free rate when they invest in the alternative asset and take a corresponding long position in the perpetual futures market.

Each household may thus buy a share in all macro futures markets. Presumably, institutions would be set up to make this more convenient. Longs would be providing insurance services to individuals who hedge their income risks, and for them the backwardation provides some recompense, something like an insurance premium. A household in the $i$ th market may buy at time $t, f_{i t} / \Sigma(i-1, N) f_{i t}$ units of a portfolio of world futures contracts, each contract of this portfolio having settlement at time $t$ equal to the sum of the settlements in all world futures contracts. (It is assumed here that the constant of proportionality in the income index to actual total income is the same in each contract). The household will then be in effect swapping the income $r_{t} f_{0}$ acquired after hedging its own income for the average income of the world.

In this scenario, in which every household opts to receive the world market return, there is no net demand created by the future markets for the alternative asset. The alternative asset may move internationally to offset fluctuations in income present values, although other assets may also serve this purpose.

The average household may be regarded as unaffected by backwardation. If the average household is long in the world macro futures market as much as it is short in its own, then the insurance premium that it pays to ensure its own income is offset by the insurance premium it receives for bearing its share of the world risk. We would not expect to see any net cost for insuring the average individual income, since all that people are doing, who are short in their own income and long in world income, is pooling their income and sharing it, and there is no insurance cost to such pooling. However, households whose own income present value is a relatively high part of world uncertainty may expect to see more backwardation in their own market, and thus will find that they are paying a net positive insurance premium to reduce their income uncertainty. Households whose income present value is a relatively low part 
of world uncertainty may expect to be primarily beneficiaries of backwardation, since they will be bearing more than their share of the risk.

The backwardation may not be very great: the diversification around the world of income risks around the world may largely wipe out income risk. ${ }^{21}$ We have seen that there is relatively little uncertainty to a fully diversified international portfolio, suggesting that the insurance premium might be small. ${ }^{22}$

Neither suppliers nor demanders would likely want to hedge the full valuc of the labor currently supplied or demanded in the current market, because of the possibility of mobility across regions or job categories, but it would be natural for them to hedge a substantial part of that labor.

It should also be noted that if indeed everyone who is short in a regional futures market desires to be long in the world futures market, then it might be advantageous to use the world macro futures market return as the alternative asset return in the settlement formula. Each futures contract would then be in effect a swap of the return on a specific claim on income for the return on a claim on world income. With such an alternative asset used for settlement, there may hardly be any total risk for longs in the futures markets, as the sum of the settlements of shorts would be approximately zero. In fact, if the return $r_{t-1}$ on the claim on world income were defined in such a way that the weights corresponding to the different specific incomes corresponded to the number of shorts in the macro futures contracts in those specific incomes, then the sum of the settlements paid to shorts would be identically zero, and the market might exist with only short sales. (Effectively, a long position in one market would be equivalent to a short position in all other markets.) Using $n_{i t-1}$ to denote the total contracts in market $i$ at time $t-1$ and $N$ as the number of futures markets, we would define $r_{t-1}$ as:

$$
r_{t-1}=\frac{\sum_{i=1}^{N} n_{i t-1}\left(f_{i t}-f_{i t-1}+d_{i t}\right)}{\sum_{i=1}^{N} n_{i t-1} f_{i t-1}}
$$

A settlement formula based on such an alternative asset return must, however, await a world market for macro futures. Probably, the practical way to start macro futures is to settle based on a world interest rate rather than something so ambitious as defined in Equation 19.

\section{Measurement Issues}

Existing aggregate income, earnings, or employment cost indices may not be ideal for the purpose of cash settling macro market contracts. The problem is that these measures may not accurately represent the path through time of individual 
endowments (of labor, human capital, unincorporated businesses, etc.) that people want to hedge. It is likely that new and better measures of national income could be developed that would account better for such things as immigration and demographic changes.

One might also consider a wage cost index rather than a national income index. The fundamental problem with hedging income risk rather than wage risk is that declines in employment status and numbers of hours worked are also offset by another benefit-declines in effort expended and increases in leisure available. For this reason, workers are not likely to view declines in income due to declines in hours worked as the same as declines in the wage rate. It is conceivable that for them there is no cost at all to declines in hours worked so long as the wage rate remains constant. Indeed, changes in the number of hours worked may largely represent changes in the desire to work. This is especially likely for long-term changes, and the perpetual futures markets are sensitive to long-term changes. We would not want to see workers receiving a settlement on their perpetual futures contracts just because they are working less because of a decision to spend more time in leisure. The firms on the other side of the contracts, hedging labor costs, would in effect be forced to pay workers the same amount even when they chose to work less.

To some extent, variations in hours worked may reflect some things other than changes in tastes. For example, there may be a secular downtrend in hours worked per week as the standard of living rises; this downtrend may have a predictable relation to the level of income, and hence, because there is virtually no uncertainty about this relation, may not have any effect on the hedging of futures markets.

\section{Obstacles to Establishment of Macro Markets}

The general public has at best an imperfect understanding of risk management. By some indications, they show signs of basic common sense. As evidence for this, note that purchase of life insurance by individuals is quite widespread. According to the Life Insurance Fact Book, $81 \%$ of U. S. households owned life insurance in 1984. But purchase of other kinds of insurance is less frequent. In 1984, only $22 \%$ of the working population carried long-term disability insurance (Cox, Gustafson and Stam 1991). There is no logical reason for people to slight disability insurance in this way. The frequency of disabilities is much higher for the working population than the frequency of deaths, although most disabilities are eventually overcome. The loss occasioned by long term disability is even larger and more catastrophic than the loss occasioned by death, since with long-term disability the family not only loses the income but also is burdened with costs of care for the disabled worker. Apparently the fear of disability has less of a sales potential for insurance agents than fear of death.

A deeper obstacle is that the general public does not properly understand hedging, and tends to view participation in futures markets as a form of gambling. 


\section{QUARTERLY REVIEW OF ECONOMICS AND FINANCE}

Helmuth (1977) found that only 5.6\% of farmers in 1976 bought or sold futures for any commodity, and that of these, most trades appeared to be for speculative, rather than hedging purposes.

Another obstacle, under present U. S. institutional arrangements, is that individuals are not permitted to trade in futures markets without setting up a futures market account. The total number of individuals who have such accounts is a small fiaction of those that deal with stockbrokers. The paperwork that the Commodity Futures Trading Commission has decreed must be filed in setting up such an account is intimidating to most people. It is designed to be intimidating: the CFTC is concerned that ignorant people could rapidly lose their fortunes in futures markets.

\section{Retail Markets}

The obstacles to direct participation in macro markets by individuals can be dealt with by retailers who provide risk management products to individuals, and who hedge in the macro markets the aggregate risk thus acquired. These retailers thus act as intermediaries between the individuals and the futures markets. These retailers would be offering services analogous to those offered to farmers by grain elevators who buy grain from farmers with forward contracts and then hedge in futures markets the aggregate risk acquired through the forward contracts. It appears that rather more grain farmers hedge indirectly through such elevators than directly through direct participation in futures markets (see Heifner, Driscoll, Helmuth, Leath, Niernberger and Wright 1977).

It would be natural for retailers to build the new risk management into existing products. For example, pension funds might alter their business to include some hedging of income risks. Employer contributions to pension funds could be debited and credited representing the employee's gains or losses in macro markets. Life or health insurance policies could be amended to include some hedging of income risk.

Or firms' guarantees of wage stability in contracts with unions could be replaced with firms' offering to pay the costs of providing hedging of income risks. A firm would not generally want to insure the individual by offering a stable wage at that firm for a long period of time. Indeed, the guarantees that firms routinely make for short contract horizons do little to insure workers against income risks. While the ability of firms to guarantee wages for a long time could be made more feasible by the possibility of hedging in macro markets, it is probably not advisable for a firm to make the guarantee in this form, since such a guarantee would lock the individual into the job at that firm. Rather, the firm should insure the individual against adverse information about his or her lifetime earnings; doing this means hedging that individual in the appropriate macro markets, the extent of the benefit being the loss the firm incurs by being short in a market with backwardation.

Income insurance policies will look a litue like speculative market instruments, paying to the beneficiary different amounts at different times. People whose objective 
is to smooth their incomes will find that their income insurance policy gives them some very nonsmooth payments. This would take some getting used to on the part of beneficiaries, who must be made to realize that the variation in payments is a natural characteristic of policies that insure them against drops in future income flows.

Those in the insurance industry are likely to find that the risk that individuals face in labor markets is rather more subject to moral hazard than are other risks. The moral hazard that insurance companies inust confront when they sell fite insurance on individual houses is the risk that people will deliberately burn down their houses to collect on their policies. Such an action is criminal, and the perpetrator runs the. risk of apprehension. In contrast, the moral hazard risk that insurance companies confront when insuring an individual against adverse shifts in his or her income includes the risk that the individual will not try hard to do well on the job, will succumb to personal and family pressures that conflict with effective work, or will become lazy. It is much easier for individuals to fail to take actions that will keep their income up, and they are not vulnerable to any criminal prosecution for this failure.

One way that insurance companies might deal with the moral hazard for income is to provide only partial insurance, that is, to sell policies only with large deductibles. Insurance companies could write such income insurance policies today, without the establishment of any macro futures markets. However, the existence of macro futures markets would facilitate their doing this, as insurance companies would find the macro futures markets a good way to lay off some of the correlated risk that they incur in the writing of these policies.

Another way that insurance companies might deal with the moral hazard problem is to write policies not on the individual's income but instead on the income index in that individual's region-occupation category. The policyholder would collect if the region-occupation wage index declined. The risk that an insurance company incurs by writing such policies could be entirely laid off in a macro futures market.

In practice, the optimal way to write such policies may be to combine both of these methods. Those who retail insurance policies should try to write policies that insure against as much of the variation in an individual's income as possible without incuming undue costs due to moral hazard. To do this optimally would mean the insurance companies could provide policies that insure fully (or nearly fully) against the declines in the region-occupation category, and partly (with a substantial deductible) against declines in the individual's wage movements relative to the index.

For any of these kinds of policies, the insurance company would sell short in the macro futures market, to hedge the risk that they incurred in writing the policies.

\section{CONCLUSION}

Evidence has been presented here that there is much aggregate income risk to be hedged in the aggregate income markets. For many of the countries that were 
studied, the variability of macro market returns are estimated to be comparable to that in stock markets; for almost all of them the standard deviation of returns is at least a few percent a year.Even risks of just a few percent a year can, if unhedged, accumulate into quite substantial variations in incomes over the years. It was shown that existing capital markets do not seem to allow cross hedging of this risk. The macro markets that are proposed in this paper are logical directions to look for reducing the effects of such variability on people's lives. Such markets might also, by extension, be considered for many other income aggregates as well, besides national income aggregates.

Economists, who have long seen the theoretical value of complete markets, have apparently thought that there was little chance that a significant expansion of markets could realistically be achieved. Yet we can draw inspiration from the extensive financial innovation that we have observed throughout the world over the past couple of decades. The financial community is receptive to new ideas if they are well justified. What would have to be done to create such markets is to define well the most important new contracts and promote their use to parties unfamiliar with them.

The apparent tendency for purely speculative price movements in financial markets is however a cause for concern about the establishment of any new markets. Presumably these markets in national incomes might sometimes boom and crash too, and there might be disruptions caused by these. One can not be sure that the establishment of macro markets would be a good thing.

Mork, Shleifer and Vishny (1990), Rhee and Rhee (1991) and Blanchard, Rhee and Summers (1993) have recently argued that stock market price changes have only a small (though statistically significant) impact on the investment decisions of firms. This might suggest that the stock market has little resource-allocation function, and that, because of the speculative bubbles in that market, there is no price discovery that is useful for the direction of resources. However, their studies are not definitive, and remain controversial. Even if they are right that prices of a firms' stock have little impact on firms' investment decisions, that may in part be because the character of firms' new investment decisions tends to bear little relation to the payoffs of their own past investments. When we set up macro futures, we must be sure, as emphasized above, that the markets to price something that can be thought of as a consistent asset or of the payoff of a certain kind of investment.

If we can trust the analogy of stock markets, the ability of aggregate income futures markets to reveal information about future dividends might be limited. It is perhaps likely that in normal times, when income is not moving a lot, price movements may be dominated by speculative pressures. On the other hand, in times when there does appear to be very important new information about the long path of future incomes, the aggregate income futures market will probably react somewhat appropriately to this information.

Even if futures price movements are not evidence of much new information about future aggregate income, the futures markets can still serve a purpose, that of 
allowing people to hedge the risk of future income fluctuations. Even if the market prices are somewhat erratic, the futures markets may still be extremely useful to hedgers, because they can, by staying in the perpetual futures market for a long time, effectively lay off the risk to their own income fluctuations. In this case, it may be considered that the information that is being revealed by short-term movements in the perpetual futures market in aggregate incomes is information about the market's willingness to take on this kind of long-tem income risk. Information about that willingness is possibly as important as information about the income itself. If this is so, it is important to have perpetual futures, rather than one-period-ahead income. futures, so that people can insure themselves against the possibility that the market will not want to bear the risk in future years.

The basic issue, moreover, is not whether such markets will have speculative bubbles, but rather whether the establishment of these markets will make speculative activity any worse. People today make essentially speculative decisions in the absence of any ability to trade macro futures. These speculative decisions are decisions whether to invest in new businesses, whether to locate businesses in a given country or region, whether to invest in human capital to go into a certain labor market. These decisions are made today without the existence of any liquid market. A firm today may locate operations in another country because of some fears about the aggregate economic situation in their own country, fears that might better have been dealt with by hedging those risks. Someone today might, let us say, forego a career in medicine because that person is bothered by rumors that that occupation is not going to be lucrative, even though that person has a comparative advantage in medicine. These decisions are just as vulnerable to fashions and fads as are decisions to invest; both are ultimately made in regard to the unseen future, both are subject to deep ambiguities that may be resolved by social forces in undesirable ways. Since the impact of the establishment of perpetual futures on speculative pressures is ambiguous, it is likely that the hedging abilities that they allow is reason enough to advocate their establishment.

The institution of markets in aggregate income might have many benefits beyond the immediate hedging function, one might say that the establishment of the markets has externalities through their effects on expectations and on other institutions. The markets might fundamentally alter the nature of the business cycle. Recent business cycle theories have stressed the importance of rigidities in prices as sources of macroeconomic fluctuations, particularly rigidities in the price of labor. It has been argued (Taylor 1980) that the tendency of firms to sign contracts with their employees that have a fixed duration (typically one to three years) is a source of persistence to macroeconomic fluctuations, since the contract length imposes rigidities for this interval of (ime. The duration of other kinds of contracts may also be important for macroeconomic fluctuations (see Fischer 1977). It is argued that the length of the business cycle (or rather, the frequency distribution of times between recessions) is fundamentally related to the length of these contracts. Long-duration contracts, such 


\section{QUARTERLY REVIEW OF ECONOMICS AND FINANCE}

as those that specify a wage rate for the duration of the contract, entail a sort of externality: firms that set these contracts do not take into account the effects that their contract has on everyone else, via the effects of the contract on the macroeconomy (Ball, 1987).

If there were futures markets in aggregate incomes, then there might be a fundamental alteration in this tendency for persistence in macroeconomic fluctuations. Both management and labor would have removed from them some incentive to make rigid contracts. Rather than sign a contract that fixes wages, they could allow wages to move with the market and hedge their risk against wage changes. ${ }^{23}$

The establishment of macro markets should tend to reduce inequality of incomes across nations or regions. In fact, to the extent that Barro (1991) and Barro and Sala-i-Martin (1992) are right, that incomes of nations or regions tend, absent any shocks, to converge to a common mean, then the establishment of markets in national incomes ought ultimately to eliminate inequalities across nations. Hedging has no effect on predictable consequences; if the tendency for convergence in incomes is predictable, then this tendency for convergence will be unaffected by any hedging of risk. The hedging of risk will instead eliminate the impact of the random shocks to income paths, shocks that prevent the convergence of incomes from ever levelling of incomes. Macro futures markets defined over aggregates other than nations may also, of course, ultimately help reduce income inequality across other groupings of people, besides nations, for which macro markets might be defined.

Acknowledgment: This research was supported by the National Science Foundation. Portions of this article were previously published in Robert Schiller's Macro Markets: Creating Institutions for Managing Society's Largest Economic Risks, Oxford University Press, 1993.

\section{NOTES}

*Direct all correspondence to: Robert J. Shiller, Yale University, Cowles Foundation, Department of Economics, 30 Hillhouse Avenue, New Haven, CT 06520-8281.

1. A discussion of futures markets that cash settle based on indices of real estate prices is in Case, Shiller and Weiss (1993).

2. Marshall, Bansal, Herbst and Tucker (1992) have proposed swaps and options on an index of consumer confidence and other macroeconomic variables.

3. Somewhat analogous instruments have already been traded, notably the index participations traded at the American Stock Exchange and the Philadelphia Stock Exchange for a few months in 1989. See Shiller (1993).

4. Both shorts and longs would be obligated by the exchange also to maintain margin accounts, and both shorts and longs could earn interest on these accounts. Equation 1 shows the total flow from shorts to longs.

5. This equation can also be derived more directly by a no-arbitrage argument. 
6. John Campbell (1993) has also independently studied the behavior of market returns in a market for a stream of future labor incomes.

7. To see this, note that $\xi_{t}$ is $-\rho$ times the innovation at time $t+1$ in $\delta_{t+1}$ (this innovation, from Equation 17, equals $-e 1^{\prime} A(I-\rho A)^{-1} \mathbf{u}_{t+1}$ ) plus the innovation at time $t+1$ in $\Delta d_{t}$ (this innovation cquals $e 1^{\prime} u_{t+1}$ ).

8. The dividend series used here starting in 1926 is dividends per share, 12 months moving total adjusted to index for the last quarter of the year, composite, as reported by Standard and Poor's Statistical Service. Values before 1926 were created by linking the Standard and Poor's series to a series produced by Alfred Cowles (1939). These nominal dividends were converted to real dividends by dividing by the Producer Price Index $1982=$ 100 for January of the succeeding year. The linked dividend series appears as Series 2 and the producer price index as Series 5 in Shiller (1989), Chapter 26.

9. Campbell and Shiller $(1988,1989)$, using similar methods, found that the stock returns were about twice as volatile as the present value model with constant discount rate would imply.

10. Since the variance matrix $\Omega$ for the error in the autoregressive model for real dividends is estimated with the usual degrees of freedom correction, the improvement of fit of the regression caused by the addition of explanatory variables does not directly reduce the estimated variance of the error as the number of explanatory variables is increased. Of course, there remains the possibility of more subtle small sample biases in this estimate.

11. The conspicuous omissions from this table are the U.S.S.R. and China.

12. The same value of $\rho$ was chosen for each country, even though different countries have historically had different growth rates, and this would suggest higher $\rho$ s for the higher growth rate countries. Implicitly I am assuming here that the risk premium in the discount rate is higher for higher growth rate countries. Of course, the volatility could be made larger or smaller by lowering or raising $\rho$.

13. The real gross national product series used here is produced by linking to the U.S. gross national product in 1987 dollars divided by the U.S. population to the Kendrick real per capita gross national product in 1958 dollars (U. S. Bureau of Economic Analysis 1973). There has been some controversy whether the apparent greater volatility of the prewar U.S. gross national product may be an artifact of earlier data collection procedures (Romer 1989; Balke and Gordon 1989).

14. Obstfeld (1993) finds that some of the lack of correlation of consumption across countries is due to differing responses across countries to oil price shocks; if this is right then some of the consumption risk could be hedged in oil futures markets.

15. The values shown in Table 1 are converted for all countries from the 1985 base year used in the Penn World Table to the 1990 base year using the U.S. implicit deflator for gross domestic product $(1987=100)$.

16. The present values for some foreign countries may seem especially high to those accustomed to using exchange rates to convert incomes to dollars. One of the most important-and stressed-results of the United Nations International Comparisons Project that gave rise to these GDP figures is that such exchange rate conversions do not give anything like an accurate sense of relative real GDPs (Summer and Heston 1988, 1991).

17. With more recent data, the correlation is higher, the correlation between the two series plotted in Figure 2 between 1964 and 1992 is $41.58 \%$. The correlation between the percentage five-year percentage growth rate in real per capita dividends and the correspond- 
ing growth rate in real per capita national income from the U.S. National Income and Product Accounts $1964-1992$ is $48.30 \%$.

18. But see Brainard and Dolbear (1971).

19. The world risk sharing described here is an extension of that discussed for real estate markets by Case et al. (1993).

20. Of course, there would likely also be markets for puts on futures, which would facilitate such partial hedging, and eliminate the risk that sudden jumps in price would vitiate the dynamic hedging strategy.

21. This is likely the ultimate reason why studies of agricultural futures market have not consistently found any evidence of backwardation; the risk of agricultural prices movements is not a substantial component of aggregate portfolio risk.

22. According to a theory in Friend and Blume (1975), the market risk premium, defined as the expected return on the market portfolio minus the risk free rate, should equal the coefficient of relative risk aversion times the variance of the market portfolio. They did not have the variance of the true world market portfolio, a number that has been estimated here perhaps for the first time.

23. There may be other macroeconomic effects as well. Abel (1988) has argued that, in theory, income insurance ought to reduce precautionary saving.

\section{REFERENCES}

[1] Abel, Andrew B. (1988). "The implications of insurance for the efficacy of fiscal policy." Journal of Risk and Insurance, 55: 339-378.

[2] Atkeson, Andrew, and Tamim Bayoumi. (1991). "Do private capital markets insure against risks in a common currency area? Evidence from the United States." Mimeo, University of Chicago.

[3] Backus, D., P. Kehoe and F. Kydland. (1992). "International real business cycles." Joumal of Political Economy, 100.745-775.

[4] Ball, Lawrence. (1987). "Externalities and contract length." American Economic Review, 77: 615-629.

[5] Barro, Robert J. (1991). "Economic Growth in a Cross Section of Countries." Quarterly Journal of Economics, 106: 407-443.

[6] Barro, Robert J. and Xavier Sala-i-Martin. (1992). "Convergence." Journal of Political Economy, 100: 223-251.

[7] Beltratti, Andrea and Robert J. Shiller. (1993). "Actual and warranted relations between asset prices." Oxford Economic Papers, 45: 387-402.

[8] Blanchard, Olivier, Changyong Rhee and Lawrence Summers. (1993). "The Stock Market, Profit and Investment." Quarterly Jourmal of Economics, 108: 115-136.

[9] Bodie, Zvi. (1990). "Pensions as Retirement Income Insurance." Journal of Economic Literature, 28: 28-49.

[10] Brainard, William. (1973). "Private and Social Risk and Return to Education." In Efficiency in Universities: The La Paz Papers, edited by R. Layard and R. Attiyah. New York: Elsevier.

[11] Brainard, William and F.T. Dolbear. (1971). "Social Risk and Financial Markets." American Economic Review, 61: 360-370.

[12] Campbell, John Y. (1993). "Understanding Risk and Return." Mimeo, Princeton University.

[13] Campbcll, John Y. and Robert J. Shillcr. (1988). "Stock Prices, Earnings, and Expected Dividends." Journal of Finance, 43: 661-676. 
[14] - (1989). "The Dividend-Price Ratio and Expectations of Future Dividends and Discount Factors." Review of Financial Studies, 1: 195-228.

[15] Case, Karl E., Robert J. Shiller and Allan N. Weiss. (1993). "Index-based futures and options markets in real estate." Journal of Portfolio Management, 19: 83-92.

[16] Cowles, Alfred. (1939). Common Stock Indexes, 1871-1937. Cowles Commission for Research in Economics, Monograph No. 3, 2nd ed. Bloomington, IN: Principia Press.

[17] Cox, Larry C., Sandra G. Gustafson and Antonie Stam. (1991). "Disability and life insurance in the individual insurance portfolio." Journal of Risk and Insurance, 58: 128-146.

[18] Fischer, Stanley. (1977). "Long term contracts, rational expectations, and the optimal money supply rule." Journal of Political Economy, 85: 191-206.

[19] Friend, Irwin, and Marshall E. Blume. (1975). "The demand for risky assets," American Economic Review, 65: 900-922.

[20] Heifner, Richard G., James L. Driscoll, John W. Helmuth, Mack N. Leath, Floyd F. Niernberger and Bruce H. Wright. (1977). "The U. S. Cash Grain Trade in 1974: Participants, Transactions, and Information Services." U.S. Department of Agriculture, Economic Research Service, Agricultural Economic Report No. 386.

[21] Helmuth, John W. (1977). Grain Pricing. Washington, DC: Commodity Futures Trading Commission.

[22] Marshall, John F., Vipul Bansal, Anthony F. Herbst and Alan L. Tucker. (1992). "Hedging business cycle risk with macro swaps and options." Continental Bank Joumal of Applied Corporate Finance, 4: 103-108.

[23] Morck, Randall, Andrei Shleifer and Robert W. Vishny. (1990). "The Stock Market and Investment: Is the Market a Sideshow?" Brookings Papers on Economic Activity, 2: 157-216.

[24] Obstfeld, Maurice. (1992). "Are industrial-country consumption risks globally diversified?" Mimeo, University of California at Berkeley.

[25] Reich, Robert B. (1992), The Work of Nations. New York: Vintage Books.

[26] Rhee, Changyong and Wooheon Rhee. (1991). "Fundamental value and investment: micro data evidence." Rochester Center for Economic Research Working Paper No. 282.

[27] Romer, Christina D. (1989). "The Prewar Business Cycle Reconsidered: New Estimates of Gross National Product 1869-1908." Journal of Political Economy, 97: 1-37.

[28] Sala-i-Martin, Xavier and Jeffrey Sachs. (1992). "Fiscal federalism and optimum currency areas: evidence for Europe from the United States." In Establishing a Central Bank: Issues in Europe and Lessons from the U. S., edited by M. B. Canzoneri, V. Grilli, and P. R. Masson. New York: Cambridge University Press.

[29] Shiller, Robert J. (1989). Market Volatility. Cambridge, MA: MIT Press.

[30] - (1993). "Measuring Asset Value for Cash Settlement in Derivative Markets: Hedonic Repeated Measures Indices and Perpetual Futures." Joumal of Finance, July.

[31] - . (1993). Macro Markets: Creating Institutions for Managing Society's Largest Economic Risks. New York: Oxford University Press.

[32] Stockman, A. and L. Tesar. (1990). "Tastes and Technology in a Two Country Model of the Business Cycle: Explaining International Comovements." Working Paper No. 3566, National Bureau of Economic Research.

[33] Summers, Robert, and Alan Heston. (1988). "A New Set of International Comparisons of Real Product and Price Levels: Estimates for 130 Countries." Review of Income and Wealth, 34: 1-25.

[34] ㄴ. (1991). "The Penn world table (Mark 5): and expanded set of international comparisons." Quarterly Journal of Economics, 106: 1-41.

[35] Taylor, John B. (1980). "Aggregate dynamics and staggered contracts." Journal of Political Economy, 88: 1-23.

[36] Tobin, James. (1973). "Financing Higher Education." Mimeo, Yale University, New Haven, CT.

[37] U. S. Bureau of Economic Analysis. (1973), Long Term Economic Growth 1860-1970. Washington, DC: U.S. Government Printing Office. 


\section{QUARTERLY REVIEW OF ECONOMICS AND FINANCE}

[38] U. S. Panel on Educational Innovation, President's Science Advisory Committee (Jerrold R. Zacharias Panel). (1967). Educational Opportunity Bank. Washington, DC: U. S. Government Printing Office.

[39] West, Kenneth D. (1988a). "Bubbles, Fads, and Stock Price Volatility: A Partial Evaluation." Journal of Finance, 43: 639-655.

[40] - (1988b). "Dividend innovations and stock price volatility." Econometrica, 56:37-61. 